\title{
Cuadernos de economía
}

Asociación

Cuadernos

de economía

www.cude.es

\section{ARTÍCULO}

\section{Is there Convergence in Emerging Countries? Evidence from Latin America}

\author{
Delbianco, Fernando (UNS, INMABB) ${ }^{a}$ and Dabús, Carlos (IIESS, UNS) ${ }^{b}$
}

a Doctor of Economics and Master in Econometrics, Universidad Nacional del Sur and INMABB-CONICET, San Andrés 800 . Bahía Blanca, D 8000 CTX, Argentina.

b Doctor of Economics, IIESS-CONICET and Universidad Nacional del Sur. San Andrés 800. Bahía Blanca, D 8000 CTX, Argentina.

\section{JEL CODES \\ C32; 041; 042}

\section{KEYWORDS:}

Economic convergence;

Unit root;

Cointegration;

Latin America

\begin{abstract}
This paper examines if there is convergence in Latin America during the 1960-2008 period, by means of the cointegration technique and unit root tests with structural breaks. The study is focused on the possible existence of convergence in the region in relation with U.S. and at intraregional level, i.e. among the different Latin American countries with respect to Argentina, the highest per capita income country of the region in this period. Despite the high economic growth of Latin America in the last decade, in general the evidence found here indicates that this was not enough to provoke convergence, neither toward U.S., nor at intraregional level. Instead, the results could suggest that the gap among the countries remain in the long run, or even the existence of divergence.
\end{abstract}

\section{CÓDIGOS JEL}

C32; 041; 042

PALABRAS CLAVE:

Convergencia Económica;

Raíz unitaria;

Cointegración;

América Latina
Resumen: Este trabajo examina la convergencia en América Latina durante el período 19602008, por medio de técnicas de cointegración a través de pruebas de raíces unitarias con cambios estructurales. El estudio se centra en la convergencia tanto de la región en relación con los EE.UU como a nivel intrarregional, es decir, entre los distintos países con respecto a la Argentina, el país con mayor ingreso per cápita a nivel regional en este período. A pesar del alto crecimiento económico de América Latina en la última década, en general, la evidencia indica que esto no fue suficiente para provocar la convergencia, ni hacia EE.UU, ni a nivel intrarregional. En lugar de ello, los resultados podrían sugerir que la brecha entre los países permanece en el largo plazo, o incluso la existencia de divergencia. 


\section{Introduction}

Convergence still holds a relevant place in the macroeconomic agenda. The theoretical foundation can be traced back to Solow (1956), who states that in presence of exogenous technical progress and decreasing returns, from an initial stock of per capita capital and income level, an economy converges to a long-run steady-state. Thereafter it grows at the rate of technical change. In turn, a set of economies with different initial conditions but similar rates of saving, depreciation, and population growth rate will converge to similar steady state equilibrium. Thus, during the transition to the steady sate poorer countries grow faster than the richest economies, so that the gap tends to close. Finally, during the process of faster growth and capital accumulation the capital marginal productivity decreases and growth rate drops, so that in the long run per capita income grows because of technical progress.

In this framework, there can be two kinds of convergence dimensions: the absolute (or unconditional) and the conditional convergence. The first is verified when all the economies converge regardless of economy-specific factors (economic policies, investment rate, composition of output, and so forth). Hence, poorer economies grow faster than richest countries, so that they trend toward the maximum per capita income level. In turn, conditional convergence occurs when the relation between the growth rate of per capita income and its initial level is negative, after controlling for the factors that condition the steady state, population growth, the parameters of preferences and the saving rate. Therefore, conditional convergence can be found in a set of similar economies.

In short, a key implication is that the poorest economy reduces or closes the gap with the richest economy in the dynamic transition to the steady state. In other words, the poorest economy grows faster than the richest, and tends to a higher income level.

Empirically, there are two concepts of convergence related to the neoclassical model: the $B$ and $\sigma$ convergence. The first is referred to those cases in which initially poorer countries grow faster than the richest economy, and then they tend to achieve its income level. In practice, this is verified when there is a negative relationship between the growth rate of per capita income and the initial per capita output level, e.g. a negative coefficient for $B$ coefficient in the convergence estimations. In turn, $\sigma$ convergence consists of a reduction of per capita income dispersion over time. This is verified when the per capita incomes cross-sectional variance between the initial and final periods under study decreases. Thus, in the last period the dispersion should be clearly lower than that at the beginning, while in the convergence process to the steady state this holds a decreasing trend. ${ }^{1}$

The convergence implications are clearly relevant, in particular those related to the fact that in the long run poor

1 However, Barro and Sala i Martin (1995) demonstrated that the existence of $B$ convergence is a necessary but not a sufficient condition for the $\sigma$ convergence. In fact, the richest countries grow less than the poorest, without a reduction of the dispersion. This occurs in those cases when the initially relatively poor countries countries can catch up with rich economies, and then improve their welfare. Moreover, it may help avoid poverty traps, which implies that in the long run poorest countries can reach higher income levels standards. Unfortunately, as it is presented in the next section, empirical evidence is not conclusive. In particular, there is not a clear consensus on whether convergence holds or not, while the evidence is noticeably disparate. In several cases this favors the existence of relative convergence, convergence clubs, or even divergence. In this sense, there exists dissimilar evidence for countries with different level of development.

For Latin America the study of this issue is particularly relevant. This should allow determine if the region can achieve a level of life similar to developed countries, as well as if poorer countries will be able to converge to the highest income economies within the region. Hence, this deserves to be more deeply analyzed. In order to reach a higher consensus with additional evidence, this paper studies the convergence in Latin America from a time-series approach. This could be a better alternative to the usual panel data and cross sectional studies. The utility of using time series approach allow us to study the series at individual level, without assuming a panel framework. This implies that it is not necessary to assume that all differences of per capita GDP share the same structure.

In turn, this paper includes the recent fast economic growth of the last decade, which has been associated with more favorable external conditions, and higher prices of commodities exported by these countries. In this sense, this paper extends the work presented by Cuñado and Pérez de García (2011) for the case of Latin America. They take into account the role of higher oil prices as a possible driver of a convergence of 13 OPEC economies toward U.S., while this paper focuses on determining whether the fast growth associated to higher commodities prices since the 2000s could provoke convergence between the region and U.S. In fact, in Latin America there is a broader sample of exportable commodities besides the oil products, so that more favorable external conditions could foster economic growth and then convergence to a higher income level.

In second place, the study is carried out at intraregional level, e.g. on the convergence of the Latin American countries to Argentina, which is the highest per capita income level economy of the region in the period under study. Thirdly, this examines the convergence into the sets of countries with high and low middle income level, which are obtained following the criterion of the World Bank classification. Finally, in order to verify if the results are robust under a different econometric approach, the work carried out in Delbianco et al. (2014) is extended. There the convergence was estimated by means of panel data, while here this is analyzed with a time series approach, by means of cointegration technique and unit root tests with structural breaks. In fact, this follows the contribution of Cuñado and Pérez de García (2011), who argue that two countries or two sets of them converge if their GDP are cointegra-

grow faster than the richer economies and surpass them, so that the dispersion of per capita income can be the same or even higher than that of the beginning. In turn, as B is a necessary condition for $\sigma$ convergence, the latter is fulfilled if there is B convergence". 
ted. The results show that there is no convergence, both between Latin America and U.S. and at intraregional level. Instead, they would indicate divergence. Thus, the contribution of this paper is to present novelty evidence on the lack of convergence both between Latin America and U.S. and at intraregional level.

The work is structured as follows. The next section presents a review of the convergence literature. Section 3 explains the methodology used in this paper, while the data are presented in section 4 . Section 5 shows the results. These indicate that, despite the high relative economic growth of the region with respect to U.S. verified during the last decade, this was not enough to allow convergence between them. Finally, section 6 concludes.

\section{Review of Convergence Literature}

Contributions can be grouped in three kinds of empirical studies: at international level for countries with similar or different development level, for regional convergence, e.g. for countries within a geographic or economic common area like the European Union and Latin America, and for regions or states of a particular country. International convergence empirical studies can be traced back since the seminal paper of Baumol (1986), which presents convergence for a sample of developed countries; likewise, more recently Rabanal (2012) also finds convergence in higher income countries. For heterogeneous samples of countries with different development level Rodrick (2011) finds absolute convergence at sectoral level for the industrial production, while Hu (2011) presents evidence of conditional convergence for a global wise sample of countries.

At regional level, for the European Union (EU) Azomahou et al. (2011) show heterogeneous convergence, that depends on the countries income level. Similarly, Cavenaile and Dubois (2011), Cuestas et al. (2012) and more recently Borsi and Netiu (2015) and von Lyncker and Thoennessen (2017) find the formation of convergence clubs. Moreover, this last contribution, in support of the club convergence hypothesis, we find that initial conditions matter for the resulting income distribution. This evidence indicates that they belong to different groups of convergence, as well as that this heterogeneity might affect the European integration stability. Contrarily, Crespo-Cuaresma et al. (2008) find that less developed countries growth faster than more advanced economies, which favors the hypothesis of $B$ convergence. Differently, Strielkowsky and Höschle (2016) present results that do not indicate much evidence on convergence within the European Union, while Goecke and Hüter (2016) find mixed evidence. Their results indicate convergence in many Eastern European countries as well as several regions in Spain and Portugal, but not for many regions in Greece, Italy and the UK. In turn, Ceylan and Abiyev (2016) analyses 15 European countries for the 1950-2015, and find that 11 of them converge to the total sample average. Meanwhile, at intra country level Moisescu (2015) finds divergence for different regions of Romania.

Similarly, for Latin America the evidence is also ambiguous. Empirical contributions show both a prevalence of conditional convergence and global divergence. Evidence for the former is laid out in Madariaga et al. (2003) for the Merco- sur in the 1985-2000 period, and Helliwell and Chung (1992) and Rincón Piedrahita (1998) for 18 Latin American countries. More recently Elías and Fuentes (2016) analyze the degree of regional economic convergence in the Southern Cone, in particular for the cases of Argentina and Chile during the 1960-1985 period, and find a more rapid convergence in the case of Chile than in the case of Argentina. In turn, Barrientos Quiroga (2010) shows the existence of convergence clubs, while Sperlich (2012) results favors the hypothesis that trade agreements promoted convergence for the cases of Mercosur. On the contrary, Cáceres (1999) and Nuñez and Sandoval (2002), by means of unit root test find regional divergence for 17 countries. More recently, King and Ramlogan-Dobson (2016) find evidence on the existence of two clubs, and Martin and Vazquez (2015) states that there are three clubs of convergence in Latin America.

For states within a country the studies also present dissimilar results. Cárdenas and Pontón (1995) for 24 departments of Colombia and Duncan and Fuentes (2006) for the Chilean regions find absolute convergence, while Coscia et al. (2017) present mixed evidence for 32 Colombian municipalities. However, Cherodian and Thirlwall (2013) show weak convergence for 32 states of Indian, while Young et al. (2013) present evidence of heterogeneous convergence, given by different rates of convergence among the U.S. states. In turn, Heather et al. (2014) find increasing internal convergence but divergence across countries. Meanwhile, the evidence presented in Royuela and García (2015) indicates the existence of social convergence in Colombia, i.e. in some key social indicators like life expectancy, infant mortality and educational enrolment, but not in a classic approach, i.e. in terms of GDP per capita.

Finally, recent contributions for wide-world countries also present heterogeneous evidence. Lessmann and Seilé (2017), in a wide-world sample, carry out and study for 1503 of 82 countries, in an average time span of 32 years, and their results reveal that approximately $67-70 \%$ of all countries experience sigma-convergence. On the contrary, Juknys et al. (2017), in a study for regions of different development stages, find that the rate of economic convergence among countries of different regions depends on the stage of their development. In fact, their evidence states that in developing regions the faster growth of richer countries leads to divergence among countries of the region, while developed areas present absolute convergence. Interestingly, Barro (2016) claims that China can be viewed as a middle-income convergence-success case, jointly with other countries like Costa Rica, Indonesia, Peru, Thailand, and Uruguay. Similarly, Lee (2017) sustains that several factors have contributed to the China's convergence towards higher per capita income levels. In special, China's low initial per capita income relative to its own long-run potential, combined with sound policy factors including a high investment rate, strong human capital, high trade openness and improved institutions, enabled the economy to converge with advanced economies. Meanwhile, in relation to the particular case of China, in a study of regional convergence find that provincial incomes are converging into two clubs: seven east-coastal provinces, like Shanghai, Tianjin, Jiangsu, Zhejiang and Guangdong, as well as in Inner Mongolia are converging into a high income club, while the remaining provinces are converging into a low income club. 
In sum, both in the studies for international samples of countries, as and at intra regional level and for different states or regions within a country, the literature of convergence shows unalike evidence.

\section{Methodology}

This section presents the methodology of time series approach that is used to estimate convergence in Latin America during the $1960-2008$ period. This detects evidence of convergence through the associated movements in GDP between two countries (or regions). If they are cointegrated, then permanent movements in one country's per capita output are in line with permanent movements in another country or region. In this sense, the difference between outputs should be stationary, i.e. unit root hypothesis should be rejected.

Most of the papers that use this approach do not find evidence of convergence (Campbell and Mankiw (1989), Cogley (1990), Bernard (1991), Carlino and Mills (1993), Bernard and Durlauf (1995), Cuñado et. al. (2003), and Beliu and Higgins (2004)). Nonetheless, some contributions that apply structural breacks detect the existence of convergence (Greasley and Oxley (1997), St. Aubyn (1999), Cellini and Scorcu (2000), Strazicich et al. (2003)).

In short, in the field of convergence empirical testing, the cointegration approach is a widely used technique, and complements the regression approach, such as cross section and panel data regressions. In turn, the introduction of structural breaks reinforces the time series study. The following sub sections present a more detailed discussion of these methodologies.

\subsection{Unit root tests and Structural Breaks}

This methodology is based in the idea of testing whether the difference between the outputs of two countries is stationary, which should indicate convergence among them. This work applies the Zivot and Andrews (1992) and Clement et al. (1997) tests. This allows a wider testing of unit root. In this sense, the Augmented Dickey - Fuller (ADF) test with three different specifications (with trend, with intercept, and without constant), that is used for testing stationarity without structural break in the series, in general finds that the series are not stationary. In turn, the common unit root test, known as the Dickey-Fuller (Dickey and Fuller, 1984) test presents a limitation: they are biased to not reject the null hypothesis of unit root in presence of structural changes, and then to detect non-stationary series. There are tests that help to identify a structural change, such as the Chow (1960) test, however prior information about the existence of a potential turning point is needed. Alternatively, breaks can be detected by iterative method.

Finally, Zivot and Andrews (1992) offers an improvement with respect to previous test: it determine endogenously the date of structural break, as it is explained below. There are three possible specifications. Model I is specified to find a change of intercept, and the maximum lag of the series is chosen by the t test. Model II only allows only changes in trend. Finally, model III evaluates the possibility of chan- ges in both intercept and trend, and uses the Akaike Information Criteria criterion (AIC) to determine the maximum number of lags of the series. For the three possible breaks specified the significance level is $5 \%$.

Model I: Model with intercept:

$\Delta y_{t}=\gamma+\alpha y_{t-1}+\beta t+\psi D I_{t}+\sum_{j=1}^{k} d_{j} \Delta y_{t-j}+\mu_{t}$

Model II: Model with trend

$\Delta y_{t}=\gamma+\alpha y_{t-1}+\beta t+\lambda D T_{t}+\sum_{j=1}^{k} d_{j} \Delta y_{t-j}+\mu_{t}$

Model III: Model with two specifications:

$\Delta y_{t}=\gamma+\alpha y_{t-1}+\beta t+\psi D I_{t}+\lambda D T_{t}+\sum_{j=1}^{k} d_{j} \Delta y_{t-j}+\mu_{t}(2$

where $\gamma$ is the intercept, $\beta t$ is the trend, $\sum_{j=1}^{k} d_{j} \Delta y_{t-j}$ are
the lags and $\mu_{t}$ is the error term.

As can be seen, the specification is not far from the Dickey-Fuller test. The difference is that it adds the $\lambda D T_{t}$, y $\psi D I_{t}$ dummies to capture a possible structural break, allowing a change in trend or intercept respectively, and it is detected endogenously.

In the three models the null hypothesis is that $\alpha=0$, i.e. there is no stationarity and there is no structural break, while under the alternative hypothesis there is stationarity and proposes a structural break at some point in the time series.

The third model has an advantage over models I and II, because it leaves open the possibility of the existence of breaks in both intercept and trend. The main idea is that either model I or model II is miss-specified, the test loses power. However, if the model III is specified, but the true underlying model is I or II, the loss of power is less (Sen (2004)). Nevertheless, in order to have more robustness in our empirical analysis we include the results of testing the three models.

Finally, to detect two structural breaks Clemente et. al. (1997) extends the Perron and Vogelsang (1992) test. Thus, the structure of this test is as follows: the null hypothesis in this test is

$H_{0}: y_{t}=y_{t-1}+\delta_{1} D T B_{1, t}+\delta_{2} D T B_{2, t}+\mu_{t}$

The alternative hypothesis has the following form:

$$
H_{1}: y_{t}=\mu+d_{1} D U_{1, t}+d_{2} D U_{2, t}+\epsilon_{t}
$$

Where $D T B_{i, t}$ is a dummy variable that takes value 1 if $t=T B_{i}+1(i=1,2)$ and 0 otherwise, while $D U_{i, t}=1$ if $t>T B_{i}(i=1,2)$ and 0 in the contrary case. Those moments in time in which the times occur are denoted by $T B_{1}$ and $T B_{2}$, which indicate the two breaks. The authors assume that the way they are the same is $T B_{i}=\lambda_{1} T(i=1,2)$ with $\lambda_{i}$ between 0 and 1 , and $\lambda_{2}>\lambda_{1} . T B_{i}=\lambda_{1} T(i=1,2)$ 
In turn, two different specifications, additive outliers (AO) and outliers innovational (IO), are introduced. In the latter case, the functional form of the unit root that is tested is:

$y_{t}=\mu+\rho_{1} y_{t-1}+\delta_{1} D T B_{1, t}+\delta_{2} D T B_{2, t}+d_{1} D U_{1, t}+$

$d_{2} D U_{2, t}+\sum_{i=1}^{k} c_{i} \Delta y_{t-1}+\epsilon_{t}$

The testing method minimizes the value of a pseudo $t$ ratio. $^{2}$

In the case of $\mathrm{AO}$, the model is tested is similar, but without the deterministic part:

$y_{t}=\mu+d_{1} D U_{1, t}+d_{2} D U_{2, t}+\hat{y}_{t}$

And the test of is performed on:

$\hat{y}_{t}=\sum_{i=0}^{k} \omega_{1, i} D T B_{1, t-1}+\sum_{i=0}^{k} \omega_{2} D T B_{2, t-1}+\rho \hat{y}_{t-1}+\sum_{i=1}^{k} c_{i} \Delta y_{t-1}+\epsilon_{t}$

The work of Clement et.al. (1997) contains finite properties and the critical values of the statistics used.

Regarding the test of Zivot and Andrews, Kim and Perron (2009) mentions:

"Zivot and Andrews assumed that if a break occurs, it does so only under the alternative hypothesis of stationarity. This is undesirable since a) it imposes an asymmetric treatment when allowing for a break, so that the test may reject when the noise is integrated but the trend is changing; $b$ ) if a break is present, this information is not exploited to improve the power of the test."

Given these two issues, Kim and Perron (KP) propose a testing procedure that allows a structural break under both the null and the alternative, and when a structural break is present, the asymptotic distribution of the test is the same as the case with a known break in the series, thus allowing increased power while maintaining a proper size test.

$\mathrm{KP}$ considers a univariate process $\mathrm{y}_{\mathrm{t}}$ generated by any of the three models of Additive Outliers (Additive Outliers, AO), or any of the two models of Innovative Outliers (Innovational Outliers, 10). For each model, the series is generated by the sum of a deterministic trend and an error term. The deterministic trend has a single break that occurs in a given period in the intercept, slope, or both, depending on the model.

The data generating processes (DGP) of the AO models are:

$\mathrm{y}_{\mathrm{t}}=\mathrm{z}\left(\mathrm{T}_{1}\right)_{\mathrm{t}}^{\prime} \phi+\mu_{\mathrm{t}}=\mathrm{z}_{\mathrm{t}, 1}^{\prime} \phi_{1}+\mathrm{z}\left(\mathrm{T}_{1}\right)_{\mathrm{t}, 2}^{\prime} \phi_{2}+\mu_{\mathrm{t}}$

where $\mathrm{z}_{\mathrm{t}+1}=(1, \mathrm{t})^{\prime}, \phi_{1}=(\mu, \beta)^{\prime}$,

2 The functional form of the ratio can be found in Clemente et.al. (1997). The assumptions made by the authors on the possible values of $\lambda$ are the same stated in Zivot and Andrews (1992), Perron and Vogelsang (1992) and Lumsdaine and Papell (1997).
$\mathrm{z}\left(\mathrm{T}_{1}\right)_{\mathrm{t}, 2}=\left\{\begin{array}{cl}\mathrm{DU}_{\mathrm{t}} & \text { Model A1 } \\ \mathrm{B}_{\mathrm{t}} & \text { Model A2 } \\ \left(\mathrm{DU}_{\mathrm{t}}, \mathrm{B}_{\mathrm{t}}\right)^{\prime} & \text { Model A3 }\end{array}, \quad \phi_{2}=\left\{\begin{array}{cc}\mu_{\mathrm{b}} & \text { Model A1 } \\ \beta_{\mathrm{b}} & \text { Model A2 } \\ \left(\mu_{\mathrm{b}}, \beta_{\mathrm{b}}\right)^{\prime} & \text { Model A3 }\end{array}\right.\right.$

with $\mathrm{DU}_{\mathrm{t}}=\mathrm{B}_{\mathrm{t}}=0$ if $\mathrm{t} \leq \mathrm{T}_{1}$, and $\mathrm{DU}_{\mathrm{t}}=1, \mathrm{~B}_{\mathrm{t}}=\mathrm{t}-\mathrm{T}_{1}$ if $\mathrm{t}>\mathrm{T}_{1}$. Here, $\mathrm{T}_{1}=\lambda^{\mathrm{C}} \mathrm{T}$, with $0<\lambda^{\mathrm{C}}<1$, that denotes the true break (and $\lambda^{\mathrm{C}}$ the true fraction that this break represents). Note that $\mathrm{DU}_{t}$ and $\mathrm{B}_{\mathrm{t}}$ depend on $\mathrm{T}_{1}$ and $\mathrm{T}$ but this dependence is omitted. The error $\left\{\mu_{t}\right\}$ is such that $\mathrm{A}(\mathrm{L}) \mu_{\mathrm{t}}=\mathrm{B}(\mathrm{L}) \varepsilon_{\mathrm{t}}$ where $\varepsilon_{\mathrm{t}} \sim$ i.i.d $\left(0, \sigma_{\mu}^{2}\right)$, and $\mathrm{A}(\mathrm{L})$ and $\mathrm{B}(\mathrm{L})$ are polynomials $\mathrm{L}$ of order $\mathrm{p}+1$ and $\mathrm{q}$, respectively. $A(L)$ is factored as $(1-\alpha L) A^{*}(L)$ and is assumed that $\mathrm{A}^{*}(\mathrm{~L})$ and $\mathrm{B}(\mathrm{L})$ have roots strictly outside the unit circle. The null and alternative hypothesis are $\mathrm{H} 0: \alpha=1$ and $\mathrm{H} 1:|\alpha|<1$, respectively. The specified ARMA model can be relaxed to allow even more general processes, but uses these specifications to facilitate the presentation of the test. The DGP of the innovational outlier (IO) models under the null hypothesis are given by:

$\mathrm{y}_{\mathrm{t}}=\mathrm{y}_{\mathrm{t}-1}+\beta+\Psi^{*}(\mathrm{~L})\left(\mathrm{d}\left(\mathrm{T}_{1}\right)_{\mathrm{t}, 2}^{\prime} \phi_{2}+\mu_{\mathrm{t}}\right)$

where

$\mathrm{d}\left(\mathrm{T}_{1}\right)_{\mathrm{t}, 2}=\left\{\begin{array}{cc}\mathrm{D}\left(\mathrm{T}_{1}\right)_{\mathrm{t}} & \text { Model I1 } \\ \left(\mathrm{D}\left(\mathrm{T}_{1}\right)_{\mathrm{t}}, \mathrm{DU}_{\mathrm{t}}\right)^{\prime} & \text { Model I3 }\end{array}\right.$

and $\mathrm{D}\left(\mathrm{T}_{1}\right)_{\mathrm{t}}=1$ if $\mathrm{t}=\mathrm{T}_{1}+1$ and 0 otherwise.

Under the alternative hypothesis:

$\mathrm{y}_{\mathrm{t}}=\mathrm{z}_{\mathrm{t}, 1}^{\prime} \phi_{1}+\Psi(\mathrm{L})\left(\mathrm{z}\left(\mathrm{T}_{1}\right)_{\mathrm{t}, 2}^{\prime} \phi_{2}+\varepsilon_{\mathrm{t}}\right)$

where

$\mathrm{z}\left(\mathrm{T}_{1}\right)_{\mathrm{t}, 2}=\left\{\begin{array}{cc}\mathrm{DU}_{\mathrm{t}} & \text { Model I1 } \\ \left(\mathrm{DU}_{\mathrm{t}}, \mathrm{B}_{\mathrm{t}}\right)^{\prime} & \text { Model I3 }\end{array} \phi_{2}=\left\{\begin{array}{cc}\mu_{\mathrm{b}} & \text { Model I1 } \\ \left(\mu_{\mathrm{b}}, \beta_{\mathrm{b}}\right)^{\prime} & \text { Model I3 }\end{array}\right.\right.$

with $\Psi^{*}(\mathrm{~L})$ and $\Psi(\mathrm{L})$ such that $\Psi^{*}(\mathrm{~L})=\mathrm{A}^{*}(\mathrm{~L})^{-1} \mathrm{~B}(\mathrm{~L})$ and $(1-\alpha \mathrm{L})^{-1} \Psi^{*}(\mathrm{~L})=\Psi(\mathrm{L})$.

The authors point out at this point that the models A1, A2, A3 (with $\mu_{\mathrm{b}}=\mathrm{c}+\beta_{\mathrm{b}} \mathrm{T}_{1}$ ), I1 and I3 (with $\mu_{\mathrm{b}}=\mathrm{c}+\beta_{\mathrm{b}} \mathrm{T}_{1}$ ) are the same as in Perron (1989), except that the structural change is unknown (i.e. the potential date of the break is unknown).

Here, it should be noted that what is done is to test first a test similar to the test implemented in Perron (1989), but instead of using the actual date break, using an estimate of the same. The Perron procedure tests the unit root hypothesis on the sum of the autoregressive coefficients of the regression on the series that was previously removed the trend (for both $\mathrm{AO}$ and 10 models). The result of this test is that $\mathrm{t}_{\alpha}\left(\lambda^{\mathrm{C}}\right) \Rightarrow \mathrm{R}\left(\lambda^{\mathrm{C}}\right)$. So, using an estimation of $\lambda$, the desirable condition is that $\mathrm{t}_{\alpha}\left(\hat{\lambda}^{\mathrm{C}}\right) \Rightarrow \mathrm{R}\left(\hat{\lambda}^{\mathrm{C}}\right)$. If this result holds, then one can use the critical values for the case where $\lambda$ is known. 
To estimate the break, Kim and Perron (2009) focus on the method to minimize SSR. Then KP's work shows that the condition mentioned is true under certain assumptions, depending on the case of DGP in question. To fulfill this condition, as mentioned at the beginning of this subsection, the size improvement to be working with the distribution as if the breakdown was known rather than unknown.

\subsection{Testing convergence}

The series used to test the unit root in this work arises from the difference between the per capita outputs, as follows:

$\Delta R I_{t}=\alpha_{0}+\alpha_{1} t+\beta R I_{t-j}+e_{t}$

where $R I_{t}=\ln \left(y_{t}^{i}\right)-\ln \left(y_{t}^{j}\right)$ i.e. is the difference of per capita income between countries $i$ and $j$. The lags are denoted by $\mathrm{p}$, which are included to prevent problems of autocorrelation. Then, this formula is used to estimate unit root tests with the presence of structural breaks.

Specifically, in first place the convergence is evaluated by applying the stationarity test on the difference of each Latin American country and U.S. per capita income levels. Secondly, the convergence between the Latin American average income and U.S. is examined. Finally, in third place the study is carried out at intra-regional level, i.e. between each country of the region and the highest real per capita income in the region (Argentina), and then into groups of middle high income and the middle low per capita GDP economies generated by the ATLAS classification, which can be found in the World Bank homepage. ${ }^{3}$

\section{Data}

This study employs annual per capita GDP data of U.S. and 19 Latin American countries for the 1960-2008 period. ${ }^{4}$ The data are expressed in constant dollars of 2000; they were extracted for the World Bank and the ECLAC database, respectively. This period was chosen in order to work with a homogeneous sample, because the ECLAC database contains and homogenized data from 1950 to 2008, while the World Bank homogeneous database for U.S. encompasses the 1960-2008 period.

Table 1 summarizes the data for the countries under study, which were grouped into low and high middle per capita income level following the World Bank classification. In turn, they were classified from the ATLAS criterion, i.e. by taking their per capita income level at the end of the period, i.e. in 2008. Thus, the countries were grouped according to their per capita income level in middle low and middle high income level. The first includes those countries of a per capita income between USD 976 and USD 3.855, while the second is referred to the range between USD 3855 and USD 11.905. Finally, countries with a income lower than USD 976

3 ATLAS: http://datos.bancomundial.org/quienes-somos/clasificacion-paises

4 As usual in the economic growth and convergence literature, per capita GDP approximates per capita income level. In turn, two sources for data were used because a complete data set of U.S. per capita GDP could be extracted from the World Bank Database, while the same set for Latin American were obtained from Economic Commission for Latin America and Caribbean (ECLAC) Database. corresponds to low income, and those that are above the threshold of USD 11.905 belong to high income.

Table 1: Countries Ordered by Real per capita GDP Level in 2008

\begin{tabular}{|c|c|c|}
\hline PC GDP in 2008 & Country & $\begin{array}{l}\text { Income } \\
\text { Group }\end{array}$ \\
\hline $48,951.0$ & U.S. & High \\
\hline $9,952.5$ & Argentina & MH \\
\hline $8,181.0$ & Uruguay & $\mathrm{MH}$ \\
\hline $7,116.3$ & Mexico & $\mathrm{MH}$ \\
\hline $6,247.8$ & Chile & $\mathrm{MH}$ \\
\hline $5,969.4$ & Venezuela & MH \\
\hline $5,593.0$ & Panama & MH \\
\hline $5,151.2$ & Costa Rica & MH \\
\hline $4,863.0$ & Latin America & . \\
\hline $4,374.9$ & Brasil & MH \\
\hline $3,594.1$ & Dominican Republic & ML \\
\hline $2,990.1$ & Peru & ML \\
\hline $2,879.4$ & Colombia & ML \\
\hline 2272.6 & El Salvador & $M L$ \\
\hline 1704.7 & Ecuador & $M L$ \\
\hline 1700.2 & Guatemala & ML \\
\hline 1522.6 & Paraguay & ML \\
\hline 1452.8 & Honduras & ML \\
\hline 1134.2 & Bolivia & $M L$ \\
\hline 896.4 & Nicaragua & Low \\
\hline 391.5 & Haiti & Low \\
\hline
\end{tabular}

Note: MH and ML denotes Mid-High and Mid-Low income group.

The ECLAC database contains 19 countries, from which two of them correspond to the Caribbean zone: Haiti and Dominican Republic, while the rest belong to Latin America. In first place, the table shows the average economic growth of U.S. and Latin America along 1960-2008 and for the almost six decades of the total period. Except during the 70's, and particularly in the last decade, U.S. has grown faster than Latin America. This is more evident for the total period, and in special during the 80 's, when this region had its worst performance, with a global negative average economic growth rate.

Similarly, figure 1 shows the difference between U.S. and Latin America GDP evolution. There is a transitory reduction from the late 60 's to 1980 , and thereafter a very high increase until the beginning of the 2000's. Finally, in the last decade this trend is reversed and then this and decreases abruptly. However, such difference still remains in substantially higher levels than the average of the total period, and especially higher in relation to the first two decades of the period under study. In turn, along the total period this trend should indicate a divergence, or at least evidence of non convergence toward U.S. and the region, which will be verified below.

On the other hand, Figure 2 presents the per capita GDP gap evolution between Argentina and the average of the rest of Latin American countries. This presents a reduction for the total period, and particularly until 1990 and during 
Table 2: Average Economic Growth of U.S. and Latin America Real Per Capita GDP, 1960-2008

\begin{tabular}{|c|c|c|c|c|c|c|}
\hline Country/Decades & $1960-2008$ & $1960-1970$ & $1970-1980$ & $1980-1990$ & $1990-2000$ & $2000-2008$ \\
\hline U.S. & 2.16 & 2.9 & 2.13 & 2.3 & 2.17 & 1.06 \\
\hline Latin America & 1.76 & 2.65 & 3.32 & -0.85 & 1.49 & 2.27 \\
\hline HM Countries ${ }^{1}$ & 2.27 & 2.68 & 3.14 & -0.26 & 2.86 & 3.12 \\
\hline Argentina & 1.48 & 2.85 & 0.98 & -2.49 & 2.96 & 3.47 \\
\hline Brazil & 2.33 & 2.65 & 6.22 & -0.42 & 0.99 & 2.17 \\
\hline Chile & 2.48 & 1.94 & 1.23 & 1.45 & 4.81 & 3.08 \\
\hline Costa Rica & 2.23 & 2.77 & 3.02 & -0.23 & 2.7 & 3.04 \\
\hline Mexico & 2.11 & 3.69 & 3.6 & -0.06 & 1.78 & 1.37 \\
\hline Panama & 2.88 & 4.87 & 2.9 & -0.56 & 2.99 & 4.52 \\
\hline Uruguay & 1.75 & 0.57 & 2.67 & -0.12 & 2.42 & 3.6 \\
\hline Dominican Republic & 2.93 & 2.12 & 4.46 & 0.35 & 4.2 & 3.67 \\
\hline LM Countries $^{2}$ & 1.44 & 24.54 & 2.62 & -1.03 & 1.05 & 2.56 \\
\hline Bolivia & 1.1 & 3.12 & 1.47 & -1.97 & 1.39 & 1.64 \\
\hline Colombia & 2.08 & 2.12 & 3.11 & 1.3 & 0.94 & 3.11 \\
\hline Ecuador & 2.05 & 1.45 & 5.96 & -0.43 & 0.03 & 3.5 \\
\hline El Salvador & 0.86 & 2.21 & -0.04 & -1.36 & 2.49 & 1.04 \\
\hline Guatemala & 1.46 & 2.71 & 2.97 & -1.47 & 1.73 & 1.31 \\
\hline Honduras & 1.35 & 1.51 & 2.35 & -0.56 & 0.87 & 2.93 \\
\hline Paraguay & 1.92 & 203 & 6.07 & 0.25 & -0.51 & 1.75 \\
\hline Peru & 1.34 & 2.36 & 1.01 & -3.1 & 2.42 & 4.69 \\
\hline Venezuela & 0.76 & 2.38 & 0.67 & -1.92 & 0.08 & 3.07 \\
\hline Nicaragua & 2.1 & 3.74 & -2.07 & -3.59 & 1.91 & 1.37 \\
\hline Haiti & -0.69 & -1.11 & 3.27 & -2.93 & -1.69 & -1.07 \\
\hline
\end{tabular}

1,2 High Middle and Low Middle per capita GDP countries, respectively.

the Argentinean crisis of 1998-2002. However, it turns up abruptly during the last decade, so that there is not clear evidence of a sustained trend that could indicate a convergence process.

Figure 1: Differences in Real Per Capita GDP between U.S. and Latin America, 1960-2008

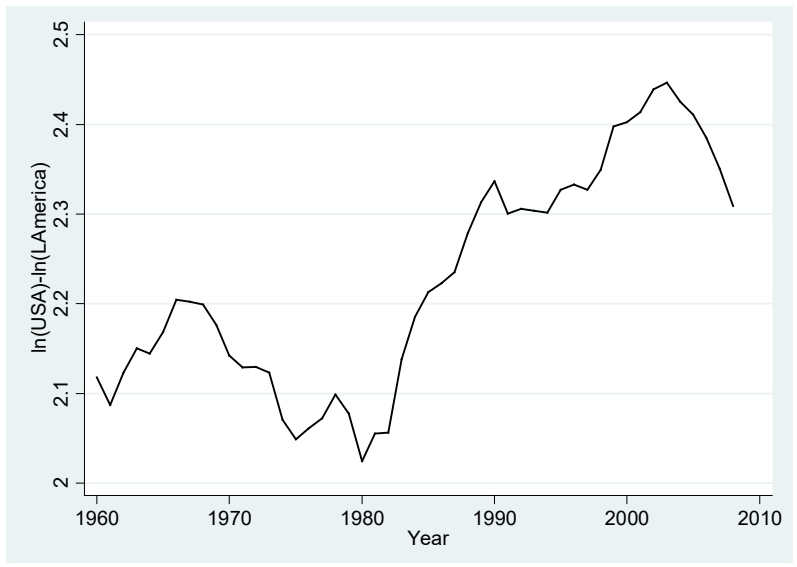

Source: Estimated in base of CEPAL and World Bank.

Note: the graph of differences in each country with U.S. is not included because each follows a very similar to the average shown in this graph, so that does not add additional information evolution.
Figure 2: Differences in Real Per Capita GDP (Argentina (Arg) and the Average or the Rest of Latin America (LAmerica), 1960-2008)

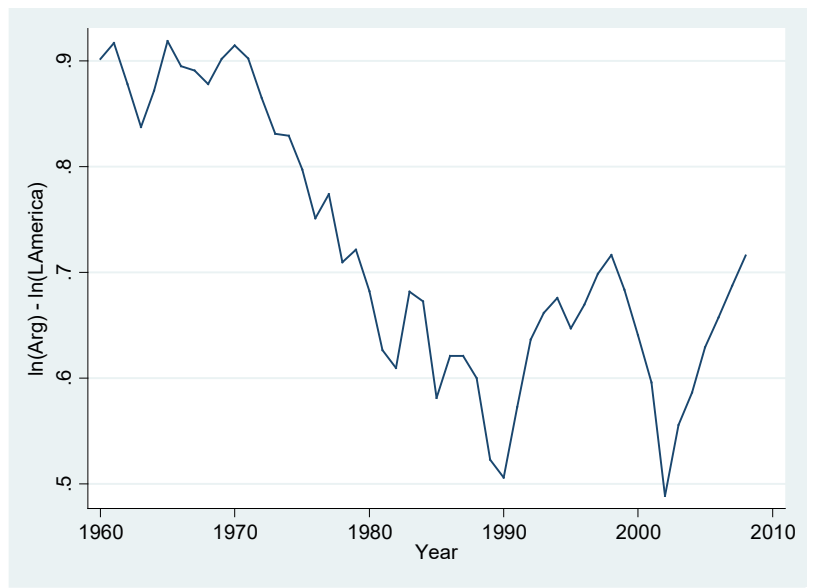

Source: Estimated in base of CEPAL.

Note: the graph of differences in each country with Argentina is not included because each follows a very similar to the average shown in this graph, so that does not add additional information evolution. 


\section{Non Convergence}

This section presents empirical evidence on the study of convergence for Latin America. This was carried out by applying unit roots tests to each country or group of countries in relation to the highest income economy, and the results indicate that there is no convergence, neither toward U.S. nor at intra regional level. Results are presented from table 3 to table 7 . In most cases they indicate non convergence. Moreover, this evidence is robust to the three tests applied to detect convergence in this paper, i.e. Augmented Dickey-Fuller (ADF), Zivot and Andrews (1992) and Clemente et al. (1997).

In first place, table 3 presents the results between the Latin American countries and U.S. by applying unit root tests with two potential structural breaks in the sample. Similarly to Clemente et al. (1997), they indicate non convergence. As a matter of fact, in general the null hypothesis of unit root cannot be rejected. Exceptions are the cases of El Salvador, Guatemala and Nicaragua; they show a trend to converge, but the results are not robust to the different specifications. In fact, these are found only for the Zivot and Andrews (1992) and Clemente et al. (1997) tests. Secondly, table 4 presents the results of testing the convergence between the average income level of the whole Latin American region and U.S., and once again they support the hypothesis of non convergence. The intuition can be that despite the clear reduction of the gap between them in the last decade shown in figure 1, it shrank not enough to provoke convergence for the whole period.

Table 3: Real Per Capita GDP Difference of Latin American Countries and U.S., 1960-2008
Table 4: Real per capita GDP Difference between U.S. and Latin America, 1960-2008

\begin{tabular}{ll} 
Test & Difference between U.S. and Latin America \\
\hline ADF & -0.876 \\
\hline ZA I & 1983 \\
\hline ZA T & 1975 \\
\hline ZA I+T & 1983 \\
\hline CLEM IO & 1968 \\
\hline & $1981^{* * *}$ \\
\hline & ns \\
\hline CLEM AO & $1985^{* * *}$ \\
\hline & 2000 \\
\hline & ns
\end{tabular}

${ }^{*},{ }^{* *}, * * *$ : significant at $10 \%, 5 \%$ and $1 \%$ respectively.

$s$, ns: significant and not significant (al $5 \%$ ).

On the other hand, the evidence presented in table 5 also shows non convergence at intra regional level, between each Latin American country in relation to Argentina, which was the highest per capita income country during the total period. In turn, the study was carried out at intra group level, i.e. for the set of low and high middle income countries. In this case there is no convergence in relation to Argentina. Finally, in order to check robustness, the unit root tests were applied to the middle low income countries with respect to both Dominican Republic and Peru, i.e. the highest per capita GDP economies within this group during all the period under study. This is because the former

\begin{tabular}{|c|c|c|c|c|c|c|c|c|c|c|c|}
\hline Country & Test & ADF & ZA I & ZA T & $\mathrm{ZA} \mathrm{I+T}$ & $\begin{array}{l}\text { CLEM } \\
10\end{array}$ & & $\begin{array}{l}\text { CLEM } \\
\text { AO }\end{array}$ & & & \\
\hline Argentina & MA & -1.326 & 1984 & 2001 & 1984 & $1982^{* * *}$ & 1997 & ns & $1982^{* * *}$ & $2000^{* * *}$ & ns \\
\hline Bolivia & $M B$ & -0.459 & $1983^{*}$ & 2001 & 1983 & $1981^{* * *}$ & $1997^{* *}$ & ns & $1985^{* * *}$ & $2001^{* *}$ & ns \\
\hline Brasil & $M A$ & -1.184 & 1971 & 1976 & 1979 & $1969^{* * *}$ & $1986^{* * *}$ & ns & $1972^{* * *}$ & $1991^{* * *}$ & ns \\
\hline Chile & MA & -0.724 & 1972 & 1984 & 1982 & $1970^{* * *}$ & $1989^{* * *}$ & ns & $1974^{* * *}$ & $1993^{* * *}$ & ns \\
\hline Colombia & $M B$ & -1.741 & 1998 & 1970 & 1999 & 1973 & $1996^{* * *}$ & ns & 1972 & $2000^{* * *}$ & ns \\
\hline Costa Rica & MA & -1.093 & 1981 & 2001 & 1981 & $1968^{* * *}$ & $1979^{* * *}$ & ns & $1971^{* * *}$ & $1983^{* * *}$ & ns \\
\hline Ecuador & MB & -1.1 & 1972 & 1976 & 1972 & $1970^{* * *}$ & $1981^{* * *}$ & ns & $1974^{* * *}$ & $1998^{* * *}$ & ns \\
\hline El Salvador & MB & -0.934 & 1979* & 1989 & $1979^{*}$ & 1963 & $1977^{* *}$ & $\mathrm{~s}$ & $1970^{* * *}$ & $1982^{* * *}$ & $\mathrm{~s}$ \\
\hline Guatemala & MB & -0.54 & $1983^{*}$ & 1971 & 1983 & 1968 & $1981^{* * *}$ & $\mathrm{~s}$ & $1987^{* *}$ & $2001^{*}$ & ns \\
\hline Haiti & $B$ & -0.288 & 1974 & 1980 & 1974 & $1982^{* * *}$ & $1990^{* *}$ & ns & $1986^{* * *}$ & $1995^{* * *}$ & ns \\
\hline Honduras & $M B$ & -1.565 & 1986 & 2001 & 1999 & $1981^{* * *}$ & 1992 & ns & $1984^{* * *}$ & $1995^{* * *}$ & ns \\
\hline Mexico & MA & -1.152 & 1986 & 1980 & 1986 & $1978^{* * *}$ & $1981^{* * *}$ & ns & $1971^{* * *}$ & $1987^{* * *}$ & ns \\
\hline Nicaragua & $B$ & -0.495 & 1979 & 1994 & 1998 & $1977^{* * *}$ & $1986^{* * *}$ & $\mathrm{~s}$ & $1980^{* * *}$ & $1989^{* * *}$ & ns \\
\hline Panama & MA & -1.651 & $1987^{*}$ & 1970 & 1987 & $1978^{* *}$ & $1985^{* * *}$ & ns & $1980^{* * *}$ & $1985^{* * *}$ & ns \\
\hline Paraguay & MB & -0.921 & 1974 & 1981 & 1977 & $1972^{* * *}$ & $1996^{* * *}$ & ns & $1976^{* * *}$ & $1996^{* * *}$ & ns \\
\hline Peru & MB & -1.198 & 1983 & 2001 & 1988 & $1981^{* * *}$ & $1986^{* * *}$ & ns & $1980^{* * *}$ & $1990^{* * *}$ & ns \\
\hline Dominican Rep. & MB & -0.672 & 1984 & 2001 & 1984 & $1972^{* * *}$ & $1968^{* * *}$ & ns & $1972^{* * *}$ & $1999^{* * *}$ & ns \\
\hline Uruguay & MA & -2.596 & 1991 & 1989 & 2001 & $1979 * *$ & 1997 & ns & $1986^{* * *}$ & 2001 & ns \\
\hline Venezuela & MA & -0.829 & 1983 & 1971 & 1983 & $1981^{* * *}$ & $1997^{* *}$ & ns & $1980^{* * *}$ & $1996 * * *$ & ns \\
\hline
\end{tabular}

ADF: Augmented Dickey Fuller; ZA: Zivot and Andrews, with intercept (I), trend (T) or both; CLEM (IO), CLEM (AO):

Clemente and Montañes, Innovational outliers (IO) or additive (AO).

*, **, ***: significant at $10 \%, 5 \%$ and $1 \%$, respectively 
belongs to the Caribbean and present structural differences in relation to the rest of Latin American countries. In particular its income is more dependent on tourism, while the others have economies more related to the export of commodities. The results are presented in Tables 6 and 7, which once again indicate non convergence. ${ }^{5}$

5 Given that the sample contains only two low income countries, in this case the results on convergence at intra group level were not included. Indeed, the results show non convergence between them. Instead, Nicaragua converges to the top low middle income countries group, Peru and Dominican Republic. Thus, the evidence suggests that in the long run Haiti will remain as the only low income Latin American country (the results are disposable upon request).
In sum, the evidence found in this study indicates non convergence both between Latin America and U.S. and at intra regional level. Indeed, in most cases the results are robust to the different tests used to detect convergence. These are compatible with previous contributions of the study of convergence in Latin America that indicates the absence of convergence, the formation of clubs of convergence or even more divergence, in special with Cáceres (1999), and Nuñez and Sandoval (2002).

Table 5: Intra Regional Convergence Tests for Latin America Countries, 1960-2008

\begin{tabular}{|c|c|c|c|c|c|c|c|c|c|c|c|}
\hline Country & Type & ADF & ZA I & ZA T & $\mathrm{ZA} \mathrm{I+T}$ & $\begin{array}{l}\text { CLEM } \\
10\end{array}$ & & $\begin{array}{l}\text { CLEM } \\
\mathrm{AO}\end{array}$ & & & \\
\hline Bolivia & $M B$ & -1.57 & 1972 & 1986 & 1991 & $1970^{* * *}$ & 1983 & ns & $1973^{* * *}$ & $1981^{* * *}$ & ns \\
\hline Brasil & MA & -1.57 & 1972 & 1986 & 1991 & $1970^{* * *}$ & 1983 & ns & $1973^{* * *}$ & $1981^{* * *}$ & ns \\
\hline Chile & MA & -0.454 & 1972 & 1976 & 1973 & $1986^{* * *}$ & 1998 & ns & $1990^{* * *}$ & $1997^{* * *}$ & ns \\
\hline Colombia & $M B$ & -1.143 & 1978 & 1991 & 1985 & $1976^{* * *}$ & $1983^{* * *}$ & ns & $1977^{* * *}$ & $1986^{* * *}$ & $\mathrm{~s}$ \\
\hline Costa Rica & MA & -1.147 & 1975 & 1968 & 2001 & $1974^{* *}$ & 1997 & ns & $1974^{* * *}$ & $1991^{* * *}$ & ns \\
\hline Ecuador & $M B$ & -1.459 & 1973 & 1986 & 1972 & $1970^{* * *}$ & 1998 & ns & $1974^{* * *}$ & $1977^{* *}$ & ns \\
\hline El Salvador & $M B$ & -0.454 & 1972 & 1976 & 1973 & $1986^{* * *}$ & 1998 & ns & $1990^{* * *}$ & $1997^{* * *}$ & ns \\
\hline Guatemala & MB & -1.143 & 1978 & 1991 & 1985 & $1976^{* * *}$ & $1983^{* * *}$ & ns & $1977^{* * *}$ & $1986^{* * *}$ & $\mathrm{~s}$ \\
\hline Haiti & B & 0.044 & 1978 & 1986 & 1978 & 1962 & $1990^{* * *}$ & ns & $1995^{* * *}$ & 2000 & ns \\
\hline Honduras & $M B$ & -1.459 & 1973 & 1986 & 1972 & $1970^{* * *}$ & 1998 & ns & $1974^{* * *}$ & $1977^{* *}$ & ns \\
\hline Mejico & MA & -1.781 & 1978 & 1986 & 1978 & $1976^{* * *}$ & 1997 & ns & $1977^{* * *}$ & $2000^{*}$ & ns \\
\hline Nicaragua & $\mathrm{B}$ & -1.781 & 1978 & 1986 & 1978 & $1976^{* * *}$ & 1997 & ns & $1977^{* * *}$ & $2000^{*}$ & ns \\
\hline Panama & MA & -1.629 & 1980 & 1983 & 1980 & $1978^{* * *}$ & $1999^{* * *}$ & ns & $1977^{* * *}$ & $2000^{* * *}$ & $\mathrm{~s}$ \\
\hline Paraguay & MB & -2.078 & $2001^{* *}$ & 1998 & $1991^{* * *}$ & $1989^{* * *}$ & $2000^{* * *}$ & $\mathrm{~s}$ & $1990^{* * *}$ & $1999^{* * *}$ & s \\
\hline Peru & MB & -2.078 & $2001^{* *}$ & 1998 & $1991^{* * *}$ & $1989^{* * *}$ & $2000^{* * *}$ & $\mathrm{~s}$ & $1990^{* * *}$ & $1999^{* * *}$ & $\mathrm{~s}$ \\
\hline Dominican Rep. & $M B$ & -0.744 & 1991 & 1967 & 1971 & $1979 * * *$ & $1997^{* * *}$ & ns & $1977^{* * *}$ & $1996^{* * *}$ & ns \\
\hline Uruguay & MA & -0.747 & 1985 & 1967 & 1985 & $1976^{* *}$ & $1983^{* *}$ & ns & $1977^{* * *}$ & $1986^{* * *}$ & ns \\
\hline Venezuela & MA & -0.984 & 1994 & 1991 & 1994 & 1967 & $1992^{* * *}$ & ns & $1980^{* * *}$ & $1995^{* * *}$ & Ns \\
\hline
\end{tabular}

*, **,***: significant at $10 \%, 5 \%$ y $1 \%$ respectively.

s, ns: significant at $5 \%$; and not significant, respectively.

Table 6: Real per capita GDP Difference of Low Middle Income Countries and Dominican Republic, 1960-2008

\begin{tabular}{lllllllllllll} 
Country & Type & ADF & ZA I & ZA T & ZA I+T & $\begin{array}{l}\text { CLEM } \\
\text { IO }\end{array}$ & \multicolumn{3}{l}{$\begin{array}{l}\text { CLEM } \\
\text { AO }\end{array}$} \\
\hline Bolivia & MB & -2.602 & 1980 & 1967 & 1980 & $1978^{* * *}$ & $1995^{* *}$ & $\mathrm{~ns}$ & $1980^{* * *}$ & $1997^{* * *}$ & $\mathrm{~ns}$ \\
\hline Colombia & $\mathrm{MB}$ & -0.708 & 1998 & 1994 & 1990 & $1971^{* * *}$ & $1997^{* * *}$ & $\mathrm{~ns}$ & $1972^{* * *}$ & $1998^{* * *}$ & $\mathrm{~ns}$ \\
\hline Ecuador & $\mathrm{MB}$ & -2.6 & 1973 & 1982 & 1973 & $1991^{* * *}$ & $1996^{* *}$ & $\mathrm{~ns}$ & $1984^{* * *}$ & $1996^{* * *}$ & $\mathrm{~ns}$ \\
\hline El Salvador & $\mathrm{MB}$ & -0.083 & 1979 & 1983 & 1979 & $1967^{* * *}$ & $1977^{* *}$ & $\mathrm{~ns}$ & $1974^{* * *}$ & $1982^{* * *}$ & $\mathrm{~ns}$ \\
\hline Guatemala & $\mathrm{MB}$ & 0.356 & 1996 & 1967 & 1970 & 1979 & 1995 & $\mathrm{~ns}$ & $1977^{* * *}$ & $1997^{* * *}$ & $\mathrm{~ns}$ \\
\hline Haití & $\mathrm{B}$ & 0.779 & 1976 & 1986 & 1978 & $1979^{*}$ & $1990^{* * *}$ & $\mathrm{~ns}$ & $1974^{* * *}$ & $1995^{* * *}$ & $\mathrm{~ns}$ \\
\hline Honduras & $\mathrm{MB}$ & -0.481 & 1971 & 1968 & 1969 & $1967^{* * *}$ & $1992^{* * *}$ & $\mathrm{~ns}$ & $1971^{* * *}$ & $1995^{* * *}$ & $\mathrm{~ns}$ \\
\hline Nicaragua & $\mathrm{B}$ & 0.033 & 1979 & 1994 & 1979 & $1977^{* * *}$ & $1985^{* * *}$ & $\mathrm{~s}$ & $1980^{* * *}$ & $1990^{* * *}$ & $\mathrm{~ns}$ \\
\hline Paraguay & $\mathrm{MB}$ & -0.156 & 1977 & 1991 & 1978 & $1975^{* * *}$ & $1996^{* * *}$ & $\mathrm{~ns}$ & $1979^{* *}$ & $1996^{* * *}$ & $\mathrm{~ns}$ \\
\hline Perú & $\mathrm{MB}$ & -0.661 & 2001 & 2001 & 1989 & $1970^{* * *}$ & $1986^{* * *}$ & $\mathrm{~ns}$ & $1974^{* * *}$ & $1990^{* * *}$ & $\mathrm{~ns}$
\end{tabular}

*, **,***: significant at $10 \%, 5 \%$ and $1 \%$ respectively.

s, ns: significant and not significant (al 5\%). 
Table 7: Real per capita GDP Difference of Low Middle Income Countries and Dominican Republic, 1960-2008

\begin{tabular}{|c|c|c|c|c|c|c|c|c|c|c|c|}
\hline Country & Type & ADF & ZA I & ZA T & $\mathrm{ZA} \mathrm{I+T}$ & $\begin{array}{l}\text { CLEM } \\
10\end{array}$ & & $\begin{array}{l}\text { CLEM } \\
\text { AO }\end{array}$ & & & \\
\hline Bolivia & MB & -1.534 & 2001 & 1999 & 1981 & 1965 & 1985 & ns & $1969^{* * *}$ & 1984 & ns \\
\hline Colombia & $M B$ & -1.004 & 1999 & 1994 & $1988^{* *}$ & $1975^{* * *}$ & $1986^{* * *}$ & ns & $1979^{* * *}$ & $1990^{* * *}$ & ns \\
\hline Ecuador & MB & -1.278 & 1972 & 1991 & 1988 & 1970 & $1986^{* *}$ & ns & $1974^{* * *}$ & $1985^{* * *}$ & ns \\
\hline El Salvador & MB & -1.539 & 1988 & 2001 & 1988 & $1977^{* * *}$ & $1986^{* * *}$ & ns & 1982 & $1991^{*}$ & ns \\
\hline Guatemala & $M B$ & -1.421 & 2001 & 1999 & 1989 & $1974^{* *}$ & $1986^{* *}$ & ns & $1973^{* * *}$ & 1990 & ns \\
\hline Haití & B & 0.383 & 1976 & 1991 & 1988 & $1992^{* * *}$ & $2002^{* * *}$ & ns & $1995^{* * *}$ & $2005^{* * *}$ & ns \\
\hline Honduras & MB & -1.464 & 1988 & 1994 & 1988 & $1974^{* *}$ & $1986^{* * *}$ & ns & $1979^{* * *}$ & $1990^{* * *}$ & ns \\
\hline Nicaragua & B & -0.451 & $1979^{* * *}$ & 1995 & $1979^{* * *}$ & $1977^{* * *}$ & $1985^{* * *}$ & ns & $1980^{* * *}$ & $1989^{* * *}$ & ns \\
\hline Paraguay & $M B$ & -1.216 & 1977 & 1992 & 1988 & $1975^{* * *}$ & $1995^{* * *}$ & ns & $1979^{* * *}$ & 2001 & ns \\
\hline Rep. Dominicana & MB & -0.661 & 2001 & 2001 & 1989 & $1970^{* * *}$ & $1986^{* * *}$ & ns & $1974^{* * *}$ & $1990^{* * *}$ & ns \\
\hline
\end{tabular}

*, **,***: significance at $10 \%, 5 \%$ and $1 \%$ respectively.

s,ns: significative and not significative (al 5\%).

\subsection{Testing Robustness}

The tests that we have applied in previous sections present a weakness. They allow that the break occur only under the alternative hypothesis. In order to avoid this, we finally include the Kim-Perron (2009), which specify the break both under the null and the alternative hypothesis. Therefore, we perform the test by selecting first the break date suggested by applying the structural test proposed by Kim-Perron (2009), and then used the break to perform a unit root test over the model of Additive Outlier III, explai- ned in the methodology section ${ }^{6}$. The results are robust to the selection of an innovative approach instead the additive model. Also, it is robust to the selection of models I and II. We choose the more complete model to show in this paper. The critical values are taken from the Table IV.B of Perron (1989).

The results can be seen in table 8 . This shows that, except in the cases of Argentina and Peru, similarly to the evidence presented below, there is no evidence of convergence in no case.

6 We show AO III as an illustration of robustness. The conclusion holds if we specify an IO model, of the specifications I or II.

Table 8: Real per capita GDP Differences among Countries, 1960-2008 period. KP test results

\begin{tabular}{llll}
$\begin{array}{l}\text { Differences between GDP } \\
\text { Per Capita }\end{array}$ & $\begin{array}{l}\text { Year of the suggested break } \\
\text { by KP }\end{array}$ & Test statistic & Significance at 5\% \\
\hline Brazil - Argentina & 1988 & -3.59 & No \\
\hline Chile - Argentina & 1974 & -2.33 & No \\
\hline Colombia - Argentina & 2002 & -3.3 & No \\
\hline Ecuador - Argentina & 1970 & -3.16 & No \\
\hline Mexico - Argentina & 2001 & -2.56 & No \\
\hline Peru - Argentina & 1989 & -5.88 & Yes \\
\hline Uruguay - Argentina & 1982 & -1.69 & No \\
\hline USA- Latin America & 1982 & -2.82 & No \\
\hline USA - Argentina & 2001 & -2.48 & No \\
\hline USA - Bolivia & 1981 & -2.6 & No \\
\hline USA - Brazil & 1979 & -3.05 & No \\
\hline USA - Chile & 1974 & -2.96 & No \\
\hline USA - Colombia & 1998 & -3.17 & No \\
\hline USA - Costa Rica & 1979 & -2.84 & No \\
\hline USA - Ecuador & 1972 & -1.82 & No \\
\hline USA - El Salvador & 1978 & -2.52 & No \\
\hline USA - Guatemala & 1981 & -3.31 & No \\
\hline USA - Haiti & 1979 & -1.96 & No
\end{tabular}




\section{Conclusions}

This paper is an extension of Delbianco et al. (2014), who find non-convergence in Latin America by means of panel data. Instead, here the empirical work was carried out by applying time series approach. In order to check the robustness of the unit root tests results three different specifications were used: the classical Dickey-Fuller, and the unit root tests with breaks of Zivot and Andrews (1992) and Clemente et al. (1997). In most cases the hypothesis of unit root test cannot be rejected, both between the whole region in relation to U.S. and at intra regional level. Thus, the results indicate non convergence, or even divergence, both of Latin American countries toward U.S. In turn, the results also show no convergence at regional level for the groups of high and low middle income.

In short, the evidence found here is favorable to the hypothesis of non convergence between Latin America and U.S. This should imply that the recent better external conditions associated to higher commodity prices and economic growth for the region seems to be not enough to reverse the long run trend. Instead, they are compatible with the general consensus of divergence between developed and less developed countries.

Finally, further research should be focused on a deeper analysis of the underlying explanatory factors behind the non convergence, as well as the long run divergence of Latin America and U.S. In particular, the economic growth studies for the region can be an initial guide to provide useful insights in order to understand the factors of the poor economic performance of the region during the second half of the past century. Moreover, they could help to develop economic policies that favors a less volatile and sustained growth in the region. In this sense, Bermúdez et al. (2014) shows that economic volatility, approximated by the inflation rate and economic fluctuations, is the main determinant of the long run stagnation.

\section{References}

Atkins, F.J. and Chan, M. (2004): "Trend breaks and the Fisher hypothesis in Canada and the United States", Applied Economics, 36, 1907-1913.

Azomahou, T, El ouardighi, J, Nguyen-Van, P. and Cuong Pham, T. (2011): "Testing convergence of European regions: A semiparametric approach", Economic Modelling, 28, 1202-1210

Barrientos Quiroga, P. (2010): “Convergence Patterns in Latin America”, Economics working paper 2010-15, School of Economics and Management, Aarhus University.

Barro, R. y X. Sala-i-Martin, (1992). “Convergence”. Journal of Political Economy, 100, 223-251.

Barro, R. y X. Sala-i-Martin, (1995). "Economic Growth". New York, McGraw-Hill.

Baumol, W. (1986), "Productivity growth, convergence, and welfare: What the long-run data show". American Economic Review, 76, 1072-1085.

Barro, Robert (2016): Economic growth and convergence, Applied Especially to China, NBER Working Paper No. 21872.
Beliu, S. and Higgins, M.L. (2004): “Fractional cointegration analysis of EU convergence", Applied Economics, $36,1607-1611$.

Bernard, A.B., (1991): "Empirical implications of the convergence hypothesis", Working Paper, Center for Economic Policy Research, Standford University.

Bernard, A.B. and Durlauf, S.N. (1995): "Convergence in international output", Journal of Applied Econometrics, 10, 97-108.

Bermúdez, C., Dabús, C. and González, G. (2015), “Reexamining the Link between Instability and Growth in Latin America: a Dynamic Panel Data Estimation Using K-Median Clusters", Latin America Journal of Economics.

Borsi, Mihaly and Metiu, Norbert (2015): “The evolution of economic convergence in the European Union", Empirical Economics, 48 (2), 657-681.

Cáceres, L. and Nuñez Sandoval, O. (1999). “Crecimiento económico y divergencia en América Latina”. El trimestre económico, 66, 781-796.

Campbell, J.Y. and Mankiw, N.G. (1989): “International evidence on the persistence of economic fluctuations", Journal of Monetary Economics, 23, 319-333.

Cárdenas, M. and Pontón A. (1995). "Growth and convergence in Colombia 1950-1990". Journal of Development Economics, 47, 5-37.

Carlino, G.A., and Mills, L.O. (1993): “Are U.S. regional incomes converging? A time series analysis", Journal of Monetary Economics, 32, 335-346.

Cavenaile, L, and Dubois, D.: (2011): “An empirical analysis of income convergence in the European Union”, Applied Economics Letters, 18, 1705-1708.

Clemente, J., Montañés, A., and Reyes, M., (1998): “Testing for a unit root in variables with a double change in the mean", Economics Letters, 59, 175-182.

Cellini, R. and Scorcu, A. (2000): "Segmented stochastic convergence across the G-7 countries", Empirical Economics, 25, 463-474.

Ceylan, R. and V. Abiyev, 2016. An examination of convergence hypothesis for EU-15 countries. International Review of Economics \& Finance 45, 96-105.

Cherodian, R , and Thirlwall, A: (2013), "Regional Disparities in Per Capita Income in India: Convergence or Divergence?" University of Kent, School of Economics Discussion Papers.

Chow, G. C. (1960). "Tests of equality between sets of coefficients in two linear regressions", Econometrica, 28, 591-605.

Cogley, T. (1990): “International evidence on the size of the random walk in output", Journal of Political Economy, 98, 501-518.

Coscia, Michele, Cheston, Timothy and Ricardo Hausmann (2017): Institutions vs. Social Interactions in Driving Economic Convergence: Evidence from Colombia, HKS Working Paper No. RWP14-014.

Crespo-Cuaresma, J., Ritzberger-Grünwald, D. and Silgoner, M. (2008): "Growth, convergence and EU membership”, Applied Economics, 40, 643-656.

Cuestas, J.C., Monfort, M. and Ordóñez, J. (2012): Real convergence in Europe: a cluster analysis, Working Paper, Department of Economics, University of Sheffield.

Cuñado, J., Gil-Alana, L.A. and Pérez de Gracia (2003): "Empirical evidence on real convergence in some OECD countries", Applied Economics Letters, 10, 173-176. 
Cuñado, J. and Pérez de Gracia, F. (2011): "Structural Breaks and Real Convergence in OPEC Countries", Journal of Applied Economics, 14, 101-117.

Delbianco, F., Dabús, C., and Zinni, B. (2014): "Sobre la no convergencia en América Latina”, Estudios Económicos, 31, 57-80.

Dickey, D.A. and Fuller, W.A. (1979): “Distribution of the estimators for autoregressive time series with a unit root", Journal of the American Statistical Association, 74, 427-431.

Duncan, Fuentes (2006). "Regional Convergence in Chile: new tests, old results", Cuadernos de Economía, 43, 81-112.

Elías, Victor and Fuentes, Rodrigo (2016): Convergence in the Southern Cone. Estudios de Economía, 25(2), 179189.

Greasley, D. and Oxley, L. (1997): "Time-series based tests of the convergence hypothesis: some positive results", Economic Letters, 56, 143-147.

Goecke, Henry and Hüter, Michael (2016): Regional convergence in Europe, Intereconomics, 51 (3), 165-171.

Heather, Berry, Guillén, Mauro and Arus Hendi (2014): "Is there convergence across countries? A spatial approach", Journal of International Business Studies, 45 (4), 387-404.

Helliwell, J. and Chung, A. (1992). "Convergence and growth linkages between North and South". NBER, Working paper, 3948.

$\mathrm{Hu}$, J. (2011): “New Empirical Evidence on Economic Convergence", Journal of Cambridge Studies, 6, 103-116.

Juknys, Romualdas, Liobikiené, Genovaité and Dagiliuté, Renata (2017): Sustainability of Economic growth and convervenge in regions of different developmental stages. Sustainable Development, 25 (4), 267-287.

Kim, D. and P. Perron (2009), "Unit Root Tests Allowing for a Break in the Trend Function at an Unknown Time under Both the Null and Alternative Hypotheses", Journal of Econometrics, 148, 1-13.

King, A. and C. Ramlogan-Dobson (2016): Is there club convergence in Latin America? Empirical Economics, 51, 1011-1031.

Lee, Jong Wha (2017): China's economic growth and convergence. The World Economy, 40 (11), 2455-2474.

Lessmann, Christian and Seilé, Andre (2017): Regional inequality, convergence, and its determinants - A view from outer space, European Economic Review, 92, 110132.

Lumsdaine, R. L., and Papell, D. H. (1997): “Multiple trend breaks and the unit-root hypothesis". Review of Economics and Statistics, 79, 212-218.

Madariaga, N., Montout, S. and Ollivaud, P. (2003): "Regional convergence, trade liberalization and aglomeration of activities: an analysis of NAFTA and Mercosur cases". Maison de Sciences Economiques, Université Paris.

Martin, V. and G. Vazquez (2015): Club convergence in Latin America. The B.E. Journal of Macroeconomics, 15, 791820.

Moisescu, Elena (2015): Regional convergence. Case of Romania. Theoretical and Applied Economics, 22 (2), 183-188.

Oxley, L. and Greasley, D. (1995): “A time-series perspective on convergence: Australia, UK, and US since 1870", The Economic Record, 71, 259-270.
Perron, P. (1989) “Testing For A Unit Root In A Time Series With A Changing Mean", Journal of Business and Economic Statistics, 8, 2, 153-162.

Perron, P., and Vogelsang, T. J. (1992): “Nonstationarity and level shifts with an application to purchasing power parity”. Journal of Business \& Economic Statistics, 10, 301-320.

Rabanal, C. (2012): “Análisis de la convergencia económica internacional durante el periodo 1950-2009”, Revista de Economía Mundial, 31, 167-197.

Rincón Piedrahita, A. (1998): “Crecimiento económico en Amércia Latina. Estudio basado en el modelo neoclásico", El trimestre económico, 65, 339-362.

Rodrik, D. (2011): “Unconditional Convergence”, NBER Working Paper 17546.

Royuela, Vicente and García, Gustavo (2015): “Economic and social convergence in Colombia", Regional Studies, 49(2), 219-239.

Sen, A. (2004): "Are US macroeconomic series difference stationary or trend-break stationary?”, Applied Economics, 36, 2025- 2029.

Solow, R. (1956): "A contribution to the theory of economic growth”. Quarterly Journal of Economics, 70, 65-94.

Sperlich, S., and Sperlich, Y. (2012): "Growth and Convergence in South-South Integration Areas: Empirical Evidence”. Working Paper Series 12032.

St. Aubyn, M. (1999): "Convergence across industrialized countries (1890-1989): new results using time series methods", Empirical Economics, 24, 23-44.

Strazicich, M.C., Lee, J. and Day, E. (2003): “Are incomes converging among OECD countries? Time Series evidence with two structural breaks", Journal of Macroeconomics, 26, 131-145.

Strielkowsky, Wadin and Höschle, Felix (2016): Evidence for economic convergence in the EU: the analysis of past EU enlargements. Technological and Economic Development, 22(4), 617-630.

Tian, Xu, Zhang, Xiaoheng, Zhou, Yingheng and Yu, Xiaohua (2016): Regional income inequality in China revisited: a perspective from club convergence, Economic Modellin, $56,50-58$.

Tomljanovich, M. and Vogelsang, T.J. (2002): “Are U.S. regions converging? Using new econometric methods to examine old issues", Empirical Economics, 27, 49-62.

von Lyncker, Konrad and Thoennessen, Rasmus (2017): Regional club convergence in the EU: evidence from a panel data analysis, Empirical Economis, 52 (2), 525553.

Young, A, Higgins, M., and Levy, D. (2013): “Heterogeneous convergence”, Economics Letters, 120, 238-241.

Zivot, E. and D. Andrews (1992): "Further Evidence on the Great Crash, the Oil-Price Shock and the Unit-Root Hypothesis", Journal of Business and Economic Statistics, 10, 251-270. 